\title{
College Students' Ideological and Political Education Problem Analysis based on Micro Culture Background
}

\author{
Xianwei Yan ${ }^{1}$, Zhongyue $\mathrm{Hu}^{2}$ \\ CangZhou Medical College,hebei, cangzhou, 061001
}

Keywords: Ideological and political education; Micro culture; Problems; College education

\begin{abstract}
With the development of current network information technology in our country, based on the impact of the media culture background like "Micro-blog" and "We-chat", in Micro cultural background, the ideological and political education for college students have more challenges. In college students' education, information exchange platforms are more and in time, and the influence of college students' ideological and political work force is becoming more and more widely. The ideological and political education work in micro culture not only faces the opportunity of development, but also is experiencing serious challenges. Establish students' ideological and political philosophy under micro culture in order to take effective measures and improve the problems of ideological and political education of contemporary college students. This paper analyzes ideological and political education based on Micro cultural background.
\end{abstract}

\section{INTRODUCTION}

College students are a special group with high culture. The network culture has been changing people's thinking mode and behavior way, therefore, in ideological and political education, based on the development of network information age, in micro cultural background, are facing challenges. This paper is to introduce it in detail below.

\section{Micro CUltural baCKGROUND ANALYSES}

According to the current Internet information report in our country, during 2014 in China, the total micro-blog users reach 674 million. For the rapid development of this "we media" era, micro cultural products' influence has been raising. Micro culture, mainly disseminates culture via media platforms like Sina Weibo and Tencent WeChat, and, the content of micro culture tends to be short, so people use digital quantity "micro" with "macro" content meaning words to record and share information anytime and anywhere for people communication in a network [1]. For campus culture spreading, greatly improve application of micro culture's openness, real-time, effectiveness, and the interaction of current education of college students, especially in the aspect of ideological and political education of college students, will exert a positive influence.

\section{ANALYZE THE CURRENT SITUATION OF IDEOLOGICAL AND POLITICAL EDUCATION OF COLLEGE STUDENTS IN CHINA}

In the process of aiming at the current ideological and political education of college students, there are still some problems to be solved, thus resulting in some problems when carry on ideological and political teaching, which affects college students' learning The 18th National Congress of the Communist Party of China spirit, and reduce the ideological and political level of college students.

\section{A. Incorrect concept of life}

In our country's university students, most students are positive, but there are also complex diversification trend, often with a strong utilitarian color. Students tend to have no good outlook on life, moral values, and values, and quite a few students' individualism is also very obvious. These problems are due to the imperfect of ideological and political education in our country. 


\section{B. Unclear teaching direction}

When making ideological and political education to the students, set up correct concept of life, enable students to adapt to the needs of social and economic development, and become useful persons to the country development. Make clear students' learning direction. Under the new concept and innovation spirit, improve students' competitive consciousness. There is no consensus spirit of hard work in contemporary college students, which is due to not enough students' incentive function of ideological and political education. Students think study has no way out, even are tired of learning.

C. Students' comprehensive quality is not high

Education in China should start from students' own quality. Effectively promote Marxism, seriously carry forward Mao Zedong's thought, and comprehensively improve college students ideological and political study level. College students' comprehensive quality is not high in current campus. Leaning branch phenomenon is serious. They are only interested in their positive performance courses, care little for courses such as economics, management, politics, which means that the strength of ideological and political education of college students is not enough, and the students can't use dialectical materialism theory to solve problems, and they have no clear understanding of the problems existing in current economic development, and cannot integrate theory with practice. They have little practical ability to solve problems. Therefore, strengthening contemporary college students' ideological and political education work is very important.

\section{IDEOLOGICAL AND POLITICAL EDUCATION UNDER THE BACKGROUND OF MICRO CULTURE}

\section{A. Positive impact}

Under the influence of current network micro cultural background, college students transform their ideal faith, which affects their life values, and can make its tilt on micro culture times [2]. College students take the responsibility of society and great rejuvenation of Chinese nation [3]. As in December 2, 2015, under micro cultural background, there was a news in micro blog, "According to Zhengzhou evening news reported yesterday, Yan was born in 1994, a Zhengzhou university student of a vocational college. While summer vacation at home, he found a bird's nest in the neighbor village, and he and his friends found a ladder and got the 12 birds form the nest. After a period of time, they sold them. Then they got 4 more. However, because of these 16 birds, Yan and his friend Wang were sentenced to 10 and a half years and 10 years respectively, and concurrently imposes a fine". For this micro culture, different voices appear on the Internet. Teachers can put this news as ideological and political teaching case. Hobby is a national level 2 protect animal. Hunting of rare and endangered species of wild animals is illegal. Guide students to have an objective look at this problem in order to make clear the ideas of college students, and cultivate students to form correct ideas and make a positive impact. On December 3, 2015, in the United States' breaking news: "The case takes place in Inland Regional Center", which is to provide public welfare facilities services for the disabled. The community service Center has 670 employees to provide service for more than 30000 people who need special care. The organization's mission is to "provide one-on-one service for developmental disabilities people and help them live better"." Such micro culture can be used as education content of students' teaching material to guide students more love life, love the motherland, and cherish peace. Based on micro cultural context, seize the opportunities for development of modern micro cultural background in ideological and political education work, actively create "micro culture" education platform, and spread positive information of micro culture to undergraduates. This will have a positive effect on the students.

\section{B. Negative impact}

In micro cultural background, "micro information", "micro culture", a variety of chicken soup, all kinds of positive ideas, inversions of various events sprint with the ideology of college students. Bad micro cultural information spread among college students will have a negative effect, and make micro cultural campus network public opinion difficult to handle [4]. On July 23, 2014, under the background of micro culture, in the news event "The government won't compensate phoenix flood", the state took out 2 billion to relieve phoenix, while the government put the country's money in his 
pocket" is actually a false rumor. On December 1, 2015, Turkey president choke Putin in Paris: I can quit, dare you? Mr. Putin said Russia had intelligence to prove the existence of IS large-scale oil trading with Turkey; In the face of Mr. Putin's allegations, Turkey's president Erdogan outraged, and fight back Mr. Putin publicly: "Once this is confirmed, I won't be president, but I want to ask Mr. Putin, will you continue to be president?". For such micro cultural transmission, if with no positive guidance education, college students could produce bias in terms of values, which has serious impact on college students' ideological and political education idea, so college students will have wrong ideas on micro cultural transmission.

\section{IMPROVEMENT MEASURES OF IDEOLOGICAL AND POLITICAL EDUCATION UNDER MICRO CULTURE}

\section{A. Innovation of practical teaching method}

For micro culture background, rich ideological content, complete the ideological and political work with plans, which can enrich college students' ideological quality, make college students have more patriotic enthusiasm, and effectively extend college students' ideological and political influence. The ideological and political education teaching method in "micro culture" innovation can take active micro culture dissemination technology platform like Micro blog and We Chat, optimize and innovate ideological and political teaching law under "micro culture" [5]. Arm college students' mind with Marxism, make them be avoided under the influence of unhealthy culture, and improve the quality of education.

\section{B. Improve supervision mechanism}

In "micro culture", value college ideological education work of college students. And establish a supervision system for ideological and political education under "micro culture", actively use network technology, search for related ideological education information, so that the students can understand social hot spots through network platform. Recognize social atmosphere in the management ideas of things, take person-orientation, and ensure the security of college students' ideological and political education environment. And establish school leadership team, perfect education rules and regulations under the background of "micro culture", so as to realize the ideological and political education work in micro culture under the background of normalization and standardization development [6]. Strengthen the public opinion monitoring of college campus network, implement the spirit of $18^{\text {th }}$ National Congress of the Communist Party of China, strengthen college students' identity of ideological and political education [7], avoid students' wrong life values consciousness, and promote the healthy development of college students.

C. Involving influence of ideological and political

For micro cultural background, predict major events occur law, involve ideological and political education work, so that the students can fully express their understanding of ideological and political in Internet micro culture, and spread ideological and political education thoughts [8]. At the same time, in students' ideological and political education, help students set up the correct outlook on life. Leader Xi Jinping pointed out: "constantly improve disability rights protection system, implement the disabled equal rights such as politics, economy, society and culture, people with disabilities are fully able to have the aspirations and ability to make a significant contribution to human society". Guide students to take care of disabled groups, and have a deeper cognition and human rights understanding in the country. If students want to be debate type talents, they not only have endurance, strong will, and should be able to endure over ten hours' talkative debate. With top-notch eloquence, alliteration, rhetorical or metaphor sentences, they will come to open mouth, and undertake to students positive guidance, and make college students take this as a target for training. Student's ideological and political education should make students set up the correct direction, and make contribution to the cultivation of the talents in our country in the future.

\section{CONCLUSION}

To sum up, apply "micro culture" transmission methods and make ideological and political 
education for college students can effectively build a harmonious campus network culture and improve the timeliness for college students' education in practice, optimize and innovate traditional mode of ideological and political education and master micro cultural network position. Micro cultural background should take ideological and political education as the carrier, take advantage of micro cultural infiltration in groups, make it be turned into education idea and penetrate into the education of college students' work actively. Carry out the pertinence of ideological and political education work.

\section{REFERENCE}

[1] Kang Yan. Explore new way education courses in colleges and universities teaching based on network technology [J]; Hei Longjiang Education (Higher Education Research and Evaluation), $2012,(18): 41$ and 42.

[2] Zhou Letao, Chen Yanping. Review study of university network ideological and political education way[J]. Journal of Hubei Institute of Socialism, 2011, 14 (12) : 76-77.

[3] Deng Min. Micro blog application research in ideological and political education [J]. Theory, 2010, 21 (14) : 56-57.

[4] Gong Deping. Analyses of the influence of network on traditional relationship between teachers and students in colleges and universities ---- Zhejiang University as example [J]. Journal of Hunan Industry Professional Technology Institute, 2011,06 (34) : 45-46.

[5] Li Yixing, Wu Yue, Ping Lechuan, Zhang Shuning, Wang Dexun. Micro blog influence and governance on after 1990 university students participation in the network [J]. BBS Industry and Science and Technology, 2012, 24 (32) : 54-57.

[6] Huang Ding. Promote college students' ideological and political education work with advanced network culture construction [J]. Journal of Heihe, 2013,01 (34) : 45-46.

[7] Chen Yihong. "Micro blog" application in ideological and political education [J]. Liuzhou Vocational Technical College Journal, 2013, 24 (32) : 54-57.

[8] Lu Peizhong. Higher vocational college counselors work countermeasures study under network cultural environment [J]; Journal of Jilin Institute of Agricultural Science and Technology, 2012, 32 (11). 